\title{
THE CONSUMPTION LEVEL OF FAT, PROTEIN AND CARBOHYDRATE IN OVERWEIGHT/ OBESITY ADOLESCENTS IN MALANG, EAST JAVA
}

\author{
Reny Tri Febriani'), FX Ady Soesetijo²), Farida Wahyuning Tiyas3) \\ 1)Masters Program in Public Health, Universitas Jember \\ 2)Faculty of Public Health, Universitas Jember \\ 3)Faculty of Dentistry, Universitas Jember
}

\begin{abstract}
Background: Overweight and obesity are an alarming global public health problem. Overweight and obesity are defined as abnormal or excessive fat accumulation that may impair health. According to WHO, worldwide obesity has nearly tripled since 1975. In 2016, more than 1.9 billion adults, 18 years and older, were overweight. Of these over 650 million were obese.39\% of adults aged 18 years and over were overweight in 2016 , and $13 \%$ were obese.41 million children under the age of 5 were overweight or obese in 2016. Over 340 million children and adolescents aged 5-19 were overweight or obese in 2016. This study aimed to determine the consumption level of fat, protein and carbohydrate in overweight/ obesity adolescents in Malang, East Java.

Subjects and Method: This was a cross-sectional study conducted in some Senior High Schools in Malang, East Java, from January to February, 2018. A sample of 111 students with overweight and obese was selected for this study by proportional random sampling. The dependent variable was nutritional status. The independent variables were fat, protein, and carbohydrate consumption level. The data were collected by 2 x 24 hours food recall and analyzed by logistic regression.

Results: As many as 33 (29.7\%) study subjects consumed fat that exceeded the recommended daily allowance (RDA). Only 32 (28.8\%) of them consumed fat according to RDA. As many as 60 (54.1\%) study subjects were undergoing low carbohydrate diet.38.7\% of them had deficient fat intake. The risk of overweight increased with high fat consumption $(\mathrm{OR}=5.38,95 \% \mathrm{CI}=0.07$ to $0.93, \mathrm{p}=$ $0.038)$, high protein consumption $(\mathrm{OR}=13.28,95 \% \mathrm{CI}=2.33$ to $35.12, \mathrm{p}=0.001)$, and high carbohydrate consumption $(\mathrm{OR}=0.14,95 \% \mathrm{CI}=0.38$ to $4.15, \mathrm{p}=0.704)$.

Conclusion: The risk of overweight increases with high fat and high protein consumption in adolescents. High carbohydrate consumption does not show significant effect on the risk of overweight.
\end{abstract}

Keywords: nutrition, consumption level, overweight, obesity, adolescents

\section{Correspondence:}

Reny Tri Febriani. Masters Program in Public Health, Universitas Jember, Jl. Kalimantan I No.93, Sumbersari, East Java.

Email: reny.smkfmaharani@gamil.com. Mobile: 081232268321. 